\title{
MODEL PEMBELAJARAN INTERAKTIF DENGAN METODE TANYA JAWAB DALAM MENINGKATAN HASIL BELAJAR SISWA DI MADRASAH IBTIDAIYAH
}

\author{
Ali Murtadlo \\ IAIN Salatiga, Salatiga, Indonesia \\ murtadlolondo@gmail.com \\ Khusna Widhyahrini \\ IAIN Salatiga, Salatiga, Indonesia \\ khusna@iainsalatiga.oc.id
}

\begin{abstract}
Abstrak
Tujuan penelitian untuk mengetahui peningkatan Hasil Belajar siswa melalui Model Pembelajaran Interaktif dengan Metode Tanya Jawab. Termasuk Classroom Action Research, dengan empat tahap: perencanaan, tindakan, pengamatan, dan refleksi. Instrumen yang digunakan insrumen penilaian pelaksanaan pembelajaran, lembar soal tes awal, lembar soal siklus I dan siklus II. Data yang diperoleh dianalis secara deskriptif. Hasil analisis data bahwa kualitas pembelajaran pada siklus 1 sebesar $88,07 \%$ tergolong kategori berkualitas dan siklus 2 kualitas pembelajaran sebesar 93,03\% tergolong kategori sangat baik. Ketuntasan hasil belajar pada siklus 1 sebesar 78,57\% tergolong kategori belum tuntas dan siklus 2 Ketuntasan hasil belajar sebesar 96,43\% tergolong kategori tuntas. Jadi, dapat disimpulkan Model Pembelajaran Interaktif dengan menggunakan Metode Tanya Jawab terbukti dapat Meningkatkan Hasil Belajar siswa.
\end{abstract}

Kata Kunci: Model Pembelajaran Interaktif, Metode Tanya Jawab, Hasil Belajar siswa

\begin{abstract}
The purpose of the research was to knowing the improvement of students' Learning Outcomes through Interactive Learning Model with the Question and Answer Method. This is a Classroom Action Research, consisted of four stages: planning, action, observation, and reflection. The instrument used is the assessment instrument for the implementation of learning, the initial test question sheet, the first cycle question sheet and second cycle. The data obtained was analyzed descriptively. The results of analysis the learning quality data in the first cycle is $88.07 \%$ classified as quality category and the second cycle of learning quality data is $93.03 \%$ categorized as very good. The completeness of learning outcomes in cycle 1 is $78.57 \%$ classified as unfinished categories and cycle 2 completeness of learning outcomes is $96.43 \%$ classified as complete categories. So, it can be concluded that the Interactive Learning Model by using the Question and Answer Method is proven to be able to improve students Learning Outcomes.
\end{abstract}

Keywords: Interactive Learning Model, Question and Answer Method, Students Learning Outcomes 


\section{A. Pendahuluan}

Hakekatnya, Kurikulum 2013 merupakan pembelajaran yang lebih menitikberatkan pada prosesnya dan bukan sekedar pada hasil. Dalam prosesnya, ada 3 hal sekaligus yang harus diperoleh siswa pada setiap mata pelajaran, yakni sikap, keterampilan, dan pengetahuan. Hal ini sejalan dengan Tujuan Pendidikan Nasional yaitu mengembangkan dan mencerdaskan kehidupan bangsa Indonesia, dengan mengarahkannya menjadi manusia yang beriman dan bertaqwa terhadap Tuhan Yang Maha Esa dan berbudi pekerti luhur, serta memiliki pengetahuan dan keterampilan, kesehatan jasmani dan rohani, kepribadian yang mantap dan mandiri serta rasa tanggungjawab kepada masyarakat dan bangsa. Iklim belajar mengajar yang baik dapat menumbuhkan rasa percaya diri. Budaya belajar dikalangan masyarakat yang dapat menumbuhkan sikap dan prilaku yang kreatif, inovatif serta keinginan untuk maju (Dasna, 2015) sangat perlu dikembangkan. Maka, peran guru dalam hal ini sangat diperlukan, karena guru tidak hanya sebagai tenaga pengajar, pendidik dan pembimbing, tetapi sebagai guru juga dituntut menjadi motivator dan manager. Sebagai seorang guru akan senantiasa mendorong siswanya untuk menguasai latihan belajar serta memotivasi siswa untuk bekerja keras agar mencapai prestasi yang setinggi-tingginya, serta bekerja sama dengan siswa lainnya untuk mencapai tujuan.

Sebagai menejer, guru akan bertindak ibarat seperti manager perusahaan. Sebagaimana disampaikan Nisa Wiyati Ilahi bahwa mengajar merupakan suatu aktivitas mengatur (mengelola) lingkungan belajar sehingga tercipta suasana yang sebaik-baiknya dalam kegiatan yang berhubungan dengan peserta didik sehingga terjadi proses belajar yang menyenangkan (Nisa Wiyati Ilahi, 2016).

Untuk meningkatkan kualitas pendidikan dan sebagai ukuran keberhasilan suatu pengajaran, penggunaan model pembelajaran yang tepat dan sesuai sangat diperlukan (Marliyah, 2014), dengan tidak mengabaikan fungsi dan peranan lainnya seperti sumber belajar, media, dan lain-lainnya, yang semua itu sudah diatur dalam kurikulum pendidikan, kurikulum yang ada terus berkembang sesuai dengan perkembangan kemajuan ilmu pengetahuan dan teknologi. Hal tersebut sejalan dengan prinsip-prinsip pengembangan kurikulum yang dapat berubah menurut kebutuhan. 
Untuk membekali siswa menghadapi proses perkembangan kemajuan ilmu dan teknologi serta globalisasi yang semakin pesat, maka siswa tingkat dasar diberikan materi pelajaran IPA. Kurikulum mata pelajaran IPA adalah salah satu mata pelajaran wajib akademis disajikan di sekolah dasar atau madrasah ibtidaiyah. Disamping itu, IPA juga merupakan mata pelajaran yang mempunyai peranan sangat penting dalam pengembangan ilmu pengetahuan serta dalam upaya memanfaatkan sumber daya alam dan teknologi.

De Vito, et al. dalam Samatowa U. menegaskan bahwa pembelajaran IPA yang baik harus mengaitkan pembelajaran dengan kehidupan sehari-hari siswa. Siswa diberi kesempatan untuk mengajukan pertanyaan, mengembangkan ide-ide siswa, membangun rasa ingin tahu tentang segala sesuatu yang ada di lingkungannya, dan membangun keterampilan (skill) yang diperlukan untuk dipelajari" (Samatowa U., 2006). Sedangkan Sulistyorini S. menekankan bahwa pembelajaran IPA di tingkat dasar harus pemberian pengalaman belajar secara langsung melalui penggunaan dan pengembangan keterampilan proses dan sikap ilmiah (Sulistyorini S., 2007).

Dalam proses pembelajaran IPA, siswa diharapkan menjadi subyek pembelajaran dan berperan aktif baik secara fisik maupun secara mental (Silbermen, 2006), hal ini untuk memberikan pengalaman langsung pada siswa. Dalam hal ini siswa yang seharusnya mendominasi kegiatan-kegiatan selama proses pembelajaran berlangsung, sementara guru bertindak sebagai fasilitator.

Namun kondisi yang ditemui dilapangan tidak seperti yang diharapkan, seperti yang terjadi pada siswa kelas VI MI NU Al Huda 01 Padurenan Gebog Kudus Jawa Tengah, tingkat pemahaman siswa terhadap mata pelajaran IPA masih kurang. Salah satu faktor penyebabnya adalah penggunaan model dan metode pembelajaran yang kurang sesuai dan belum bervariasi. Penggunaan model pembelajaran yang masih bersifat eksposisi yaitu model pembelajaran yang berpusat pada guru (Haryanti, 2013), sedangkan keberadaan siswa sebagai anak yang aktif dan kreatif masih kurang diperhatikan sehingga cenderung membuat anak menjadi pasif.

Penelitian ini mengetahui aktifitas dan kreatifitas siswa dalam mengikuti proses pembelajaran di madrasah sehingga diharapkan dapat meningkatkan hasil belajar siswa. Menurut Rusman hasil belajar adalah sejumlah pengalaman yang siswa 
peroleh mencakup ranah kognitif, afektif, dan psikomotor (Rusman, 2010). Pendekatan pembelajaran penelitian ini menggunakan model pembelajaran interaktif, dengan asumsi bahwa model pembelajaran interaktif dapat meningkatkan siswa belajar aktif dan kreatif. Dengan model pembelajaran interaktif perolehan hasil belajar siswa lebih bermakna dan siswa terlibat secara penuh dalam belajar. Model pembelajaran interaktif menurut Dasna (2015) mengacu pada interaksi antara peserta didik dengan pendidik, peserta didik dengan pengajar, atau juga peserta didik dengan media/sumber belajar.

Dari hasil penelitian Nugroho Widiantono (2013) mengatakan model pembelajaran interaktif dapat meningkatkan aktivitas dan hasil belajar IPA siswa Sekolah Dasar. Sedangkan Ifan Sofian (2013) menyimpulkan juga bahwa model pembelajaran interaktif dapat meningkatkan prestasi belajar fisika siswa tingkat menengah.

Oleh sebab itu peneliti tertarik ingin melakukan suatu penelitian tindakan kelas sebagai upaya dalam melakukan perbaikan terhadap pembelajaran IPA dengan judul "Model Pembelajaran Interaktif Dengan Metode Tanya Jawab dalam Meningkatan Hasil Belajar IPA kelas VI MI NU Al Huda 01 Tahun Pelajaran 2018-2019”.

Berdasarkan uraian yang telah dipaparkan, maka rumusan masalah pada penelitian ini adalah:

1. Apakah penerapan model pembelajaran interaktif dengan metode tanya jawab dapat meningkatkan hasil belajar mata pelajaran IPA pada siswa kelas VI MI NU Al Huda 01 Padurenan Gebog Kudus Jawa Tengah Tahun Pelajaran 2018-2019?

2. Bagaimana meningkatkan hasil belajar siswa pada mata pelajaran IPA melalui metode tanya jawab dalam pembelajaran perkembangan makhluk hidup dan pelestarian jenis makhluk hidup untuk mencegah dari kepunahan di kelas VI MI NU Al Huda 01 Padurenan Gebog Kudus Jawa Tengah Tahun Pelajaran 20182019 ?

\section{Metode Penelitian}

Penelitian ini menggunakan metode Penelitian Tindakan Kelas (PTK) atau dikenal dengan Classroom Action Research model Kammis. Menurut Kammis, penelitian tindakan kelas adalah bentuk penelitian refleksi diri yang dilakukan oleh 
para partisipan dalam situasi-situasi sosial (termasuk pendidikan) untuk memperbaiki praktik yang dilakukan sendiri (Wijaya, 2013). Penelitian ini bermaksud mengungkapkan suatu upaya dalam meningkatkan kreativitas dan kemandirian belajar mahasiswa melalui model pembelajaran berbasis proyek pada mata kuliah media pembelajaran sains.

Subjek penelitian siswa kelas VI MI NU Al Huda 01 dengan jumlah siswa 28 orang, yang terdiri dari 15 siswa laki-laki dan 13 siswa perempuan. Objek penelitian meliputi kualitas pembelajaran dan ketuntasan hasil belajar siswa pada mata pelajaran IPA. Penelitian dilakukan sebanyak 2 (dua) siklus. Adapun tahapantahapan yang dilakukan pada setiap siklus adalah sebagai berikut:

1. Perencanaan

Perencanaan tindakan dimulai dari proses identifikasi masalah yang akan diteliti, termasuk hasil pra penelitian. Kemudian merencanakan tindakan yang akan dilakukan, termasuk menyusun perangkat pembelajaran yang diperlukan dan lain-lain. Pelaksanaan penelitian ini dilaksanakan dalam 1 bulan (20 Oktober s/d 20 Nopember 2018).

2. Tindakan

Merupakan pelaksanaan pembelajaran di kelas dengan menggunakan perangkat pembelajaran mulai dari kegiatan awal, kegiatan inti, hingga kegiatan akhir sesuai dengan RPP. Langkah-langkah yang ditempuh dalam penelitian dimulai dari mempersiapkan rencana perbaikan pembelajaran sebaik mungkin, menggunakan alat bantu yang tepat dan lengkap untuk menanamkan konsep pembelajaran, memperbaiki cara penyajian pembelajaran, menambahkan metode pembelajaran (tanya jawab) dan model Pembelajaran Interaktif, memberikan informasi pembelajaran yang jelas dan rinci, memberikan contoh cara memelihara lingkungan agar tetap sehat, memberikan latihan secukupnya, dan menindaklanjuti pembelajaran melalui pekerjaan rumah (Primadiati \& Djukri, 2017).

Sedangkan langkah-langkah penyusunan persiapan pembelajaran dimulai dari Standar Kompetensi, Kompetensi Dasar, Indikator Pembelajaran, Materi Pembelajaran, Kegiatan Pembelajaran dan Evaluasi Pembelajaran. 
Melaksanakan pembelajaran yang nyata berdasarkan rencana perbaikan pembelajaran yang telah disusun, tindakan ini ditujukan untuk memperbaiki keadaan atau mengatasi masalah yang ada pada kegiatan pembelajaran di kelas.

3. Pengamatan

Pengamatan dilakukan As \& Paudi (2013) dengan pemantauan terhadap kegiatan yang dilakukan. Pengamatan selama berlangsungnya kegiatan pembelajaran yang dilakukan oleh kolaborator dan/atau observer secara simultan (bersamaan pada saat pembelajaran berlangsung).

4. Refleksi

Refleksi merupakan kegiatan mengevaluasi hasil analisis data besama kolaborator yang akan direkomendasikan tentang hasil suatu tindakan yang dilakukan demi mencapai keberhasilan penelitian dari aspek/indicator.

Sesuai dengan tujuan penelitian (Wijaya, 2013), ada beberapa instrumen yang digunakan dalam penelitian ini adalah Insrumen penilaian pelaksanaan pembelajaran di kelas, lembar soal tes awal, lembar soal siklus I dan lembar soal siklus II. Lembar Instrumen penilaian pelaksanaan pembelajaran di kelas digunakan untuk menilai pelaksanaan pembelajaran di kelas. Lembar soal tes awal, lembar soal siklus I dan lembar soal siklus II disusun berdasarkan Kompetensi Dasar, yaitu untuk siklus I dengan Kompetensi Dasar mendeskripsikan perkembangan dan pertumbuhan manusia dari bayi sampai lanjut usia, dan untuk siklus II Kompetensi Dasar mengidentifikasi jenis hewan dan tumbuhan yang mendekati kepunahan, Lembar penilaian untuk mengetahui ketuntasan hasil belajar siswa. Instrumen penilaian pelaksanaan pembelajaran di kelas digunakan untuk menilai pelaksanaan pembelajaran di kelas oleh kolaborator. Instrumen penilaian pelaksanaan pembelajaran sebagai berikut: 
Tabel 1. Kisi-kisi Penilaian Pelaksanaan Pembelajaran di Kelas

\begin{tabular}{|c|c|c|c|c|}
\hline No & Kegiatan & Uraian Kegiatan & $\begin{array}{c}\text { Lembar } \\
\text { Penilaian ke- }\end{array}$ & $\begin{array}{c}\mathrm{Jml} \\
\text { Penilaian }\end{array}$ \\
\hline 1. & $\begin{array}{l}\text { Pra pembelajran } \\
\text { (kegiatan awal) }\end{array}$ & $\begin{array}{l}\text { 1. Mempersiapkan siswa untuk } \\
\text { belajar. } \\
\text { 2. Melakukan kegiatan apersepsi }\end{array}$ & $\begin{array}{l}1 \\
2\end{array}$ & 2 \\
\hline 2. & $\begin{array}{l}\text { Kegiatan Inti } \\
\text { pembelajaran }\end{array}$ & $\begin{array}{l}\text { 1. Mengeksplorasi materi } \\
\text { 2. Megelaborasi materi } \\
\text { 3. Mengkorfirmasi hasil }\end{array}$ & $\begin{array}{l}3 \\
4 \\
5\end{array}$ & 3 \\
\hline 3. & Kegiatan Akhir & $\begin{array}{l}\text { 1. Menyimpulkan } \\
\text { 2. Memberikan tugas di rumah } \\
\text { 3. Memberikan Informasi materi } \\
\text { berikutnya }\end{array}$ & $\begin{array}{l}6 \\
7 \\
8\end{array}$ & 3 \\
\hline 4. & $\begin{array}{l}\text { Penguasaan } \\
\text { Materi Ajar }\end{array}$ & $\begin{array}{l}\text { 1. Menunjukkan penguasaan } \\
\text { materi ajar } \\
\text { 2. Mengaitkan materi dengan } \\
\text { realitas kehidupan }\end{array}$ & $\begin{array}{l}9 \\
10\end{array}$ & 2 \\
\hline 5. & $\begin{array}{l}\text { Strategi } \\
\text { Pemblajaran }\end{array}$ & $\begin{array}{l}\text { 1. Menerapkan pendekatan } \\
\text { pembelajaran } \\
\text { 2. Menerapkan pendekatan } \\
\text { pembelajaran tipe jig saw } \\
\text { 3. Penerapan metode } \\
\text { pembelajaran bervarisi }\end{array}$ & $\begin{array}{l}11 \\
12 \\
13\end{array}$ & 3 \\
\hline 6. & Pemanfaatan & $\begin{array}{l}\text { 1. Menggunakan media } \\
\text { pembelajaran } \\
\text { 2. Menggunakan alat praktek } \\
\text { pembelajaran } \\
\text { 3. Memanfaatkan sumber belajar } \\
\text { 4. Memanfaatkan lingkungan } \\
\text { belajar }\end{array}$ & $\begin{array}{l}14 \\
15 \\
16 \\
17\end{array}$ & 4 \\
\hline 7. & $\begin{array}{l}\text { Pembelajaran } \\
\text { yang memicu }\end{array}$ & $\begin{array}{l}\text { 1. Menumbuhkan prtisipasi aktif } \\
\text { siswa } \\
\text { 2. Menunjukkan sikap terbuka } \\
\text { 3. Menumbuhkan antusiasme } \\
\text { siswa }\end{array}$ & $\begin{array}{l}18 \\
19 \\
20\end{array}$ & 3 \\
\hline 8. & $\begin{array}{l}\text { Penguasaan } \\
\text { Bahasa }\end{array}$ & $\begin{array}{l}\text { 1. Menggunakan bahasa lisan dan } \\
\text { tulisan yang jelas } \\
\text { 2. Menyampaikan pesan sesuai } \\
\text { dengan gaya yang sesuai }\end{array}$ & $\begin{array}{l}21 \\
22\end{array}$ & 2 \\
\hline 9. & $\begin{array}{l}\text { Penilaian Proses } \\
\text { dan Hasil Belajar }\end{array}$ & $\begin{array}{l}\text { 1. Memantau kemajuan belajar } \\
\text { selama proses } \\
\text { 2. Melakukan penilaian akhir } \\
\text { sesuai dengan tujuan }\end{array}$ & $\begin{array}{l}23 \\
24\end{array}$ & 2 \\
\hline 10 & Penutup & $\begin{array}{l}\text { 1. Melakukan refleksi } \\
\text { 2. Melaksanakan tindak lanjut }\end{array}$ & $\begin{array}{l}25 \\
26\end{array}$ & 2 \\
\hline & & Jumlah & \multicolumn{2}{|c|}{26} \\
\hline
\end{tabular}


Tabel 2. Indeks Tingkat Kesukaran Soal (p)

\begin{tabular}{|c|c|}
\hline Interval Nilai & Interpretasi/Makna \\
\hline $0,00-0,30$ & Sukar $(\mathrm{Sk})$ \\
\hline $0,31-0,70$ & Sedang $(\mathrm{Sd})$ \\
\hline $0,71-1,00$ & Mudah $(\mathrm{Md})$ \\
\hline
\end{tabular}

Table 3. Konversi Nilai

\begin{tabular}{|c|c|l|}
\hline Interval Nilai & Kategori & Makna \\
\hline $81-100$ & A & Sangat Baik \\
\hline $61-80$ & B & Baik \\
\hline $41-60$ & C & Cukup baik \\
\hline $21-40$ & D & Kurang baik \\
\hline $0-20$ & E & Jelek/sangat tidak baik \\
\hline
\end{tabular}

\section{B. Hasil Penelitian dan Pembahasan}

\section{Hasil Penelitian}

Penelitian tindakan kelas dilakukan bersama satu orang guru kelas. Penelitian kolaborasi dilaksanakan di MI NU Al Huda 01 Padurenan Gebog Kudus Jawa Tengah, dimulai kegiatan kegiatan observasi tanggal 20 Oktober 2018 dan pra penelitian, termasuk tes awal. Subjek yang diteliti adalah siswa kelas VI.

Penelitian ini dilakukan dalam rangka memperbaiki kualitas pembelajaran, perilaku siswa dengan indicator keaktifan siswa, hasil belajar pada mata pelajaran IPA melalui model pembelajaran interaktif dengan menggunakan metode Tanya jawab (Dewi \& Kristin, 2017). Adapun deskripsi data hasil penelitian adalah sebagai berikut:

1. Deskripsi Data Hasil Pra penelitian (Pra siklus)

Data Hasil Tes Awal
a) Mata Pelajaran
: IPA
b) Kompetensi Dasar
: Mendeskripsikan perkembangan dan pertumbuhan
manusia dari bayi sampai lanjut usia
c) Materi Ajar
: Perkembangbiakan makhluk hidup
d) $\mathrm{KKM}$
$: 70$
e) Tanggal Pelaksanaan Tes Awal : 20 Oktober 2018 
Tabel 1. Rekapitulasi Nilai Hasil Tes Awal Siswa Kelas VI

MI NU Al Huda 01 Padurenan Gebog Kudus

Tahun Pelajaran 2018/2019

\begin{tabular}{|c|c|c|}
\hline Ketuntasan & Jumlah Siswa & Persentase \\
\hline Tuntas & 14 & 50 \\
\hline Belum tuntas & 14 & 50 \\
\hline Jumlah & 28 & 100 \\
\hline
\end{tabular}

Tabel 1. Menunjukkan bahwa ketuntasan sebesar 50\% (14 siswa) masih jauh dari indikator keberhasilan belajar minimal 50\% yang mencapai $\mathrm{KKM}=70$ atau 50\% (14 siswa) yang belum tuntas.

2. Deskripsi Data Hasil Penelitian Siklus

Data Hasil Observasi dan Penilaian Pelaksanaan Pembelajaran di Kelas. Yang menilai pelaksanaan pembelajaran di kelas adalah kolaborator selama berlangsung proses pembelajaran, kemudian datanya ditabulasi dan direkapitulasi dengan rekapitulasi sebagai berikut:

Tabel 2. Rekapitulasi Data Penilaian Pelaksanaan Pembelajaran pada

Siklus I

\begin{tabular}{|l|c|l|}
\hline Kolaborator & Perolehan Total Skor & Interpretasi/Makna \\
\hline Mustahal, S.Pd.I & 84,61 & Berkualitas \\
\hline Ali Murtadlo, S.Pd.I & 91,53 & Berkualitas \\
\hline Jumlah & 176,14 & \\
\hline Rata-rata & 88,07 & Baik \\
\hline
\end{tabular}

Tabel 2. Menunjukkan bahwa kualitas pembelajaran yang dilakukan oleh peneliti sebesar 88,07 dengan makna berkualitas namun masih belum berkualitas dari segi aspek/indikator kegiatan inti yang meliputi kegiatan eksplorasi, kegiatan elaborasi dan kegiatan konfirmasi.

Tabel 3. Rekapitulasi Data Hasil Penilaian Pelaksanaan Pembelajaran pada Siklus II

\begin{tabular}{|l|c|l|}
\hline Kolaborator & Total Skor(\%) & Interpretasi/Makna \\
\hline Mustahal, S.Pd.I & 92,30 & Berkualitas \\
\hline Ali Murtadlo, S.Pd.I & 93,07 & Berkualitas \\
\hline Jumlah & 185,37 & \\
\hline Rata-rata & 92,69 & Sangat Baik \\
\hline
\end{tabular}

Tabel 3. Menunjukkan bahwa kualitas pembelajaran yang dilakukan oleh peneliti sebesar 92,69 dengan makna berkualitas, namun masih belum berkualitas dari segi aspek/indikator kegiatan inti yang meliputi kegiatan elaborasi dan kegiatan konfirmasi. 
3. Data Penilaian Hasil Belajar Siswa pada Mata Pelajaran IPA

Tabel 4. Rekapitulasi Nilai Hasil Belajar Siswa pada Siklus I

\begin{tabular}{|l|c|c|c|c|}
\hline Keberhasilan & Jumlah Siswa & $\%$ & KKM & Nilai Rata - Rata \\
\hline Tuntas & 22 & 78,57 & 70 & \\
\hline Belum Tuntas & 6 & 21,43 & 70 & \\
\hline Jumlah & 28 & 100 & 140 & \\
\hline Rata-rata & - & - & 70 & 70 \\
\hline
\end{tabular}

Tabel 4. Menunjukkan bahwa ketuntasan belajar sebesar $78,57 \%$ dan belum tuntas $21,43 \%$ berarti belum berhasil, karena indikator keberhasilan minimal $80 \%$, ternyata masih ada 6 siswa yang jauh ketercapaian hasil tes dibawah KKM = 70, yaitu Desi Rahma Wulandari, Ainur Rosada, Baharudin Achmad, Muhammad Farel Safaruddin, Muhammad Iqbal Khoiri, Muhammad Rizqi Firmansyah. Nilai rata-rata penilaian hasil belajar siklus I diatas KKM = 70.

Tabel 5. Rekapitulasi Nilai Hasil Belajar Siswa pada Siklus II

\begin{tabular}{|l|c|c|c|c|}
\hline Keberhasilan & Jumlah Siswa & $\%$ & KKM & Nilai Rata - Rata \\
\hline Tuntas & 27 & 96,43 & 70 & \\
\hline Belum Tuntas & 1 & 03,57 & 70 & \\
\hline Jumlah & 28 & 100 & 140 & \\
\hline Rata-rata & - & - & 70 & 70 \\
\hline
\end{tabular}

Tabel 5. Menunjukkan yang telah tuntas sebesar 96,43\% dan belum tuntas sebesar $03,57 \%$. Ternyata tinggal 1 siswa yang belum mencapai hasil tes pada KKM = 70, yaitu Muhammad Farel Safaruddin (65).

4. Rangkuman Perbaikan Hasil Penelitian Kolaborasi Siklus I dan II

Berdasarkan hasil analisis, data hasil penelitian siklus I dan II dapat dibandingkan untuk mengetahui tingkat keberhasilan penelitian sebagaimana dalam Tabel 6 di bawah ini.

Tabel 6. Rangkuman Perbandingan Hasil Penelitian Tindakan Kolaborasi Siklus I dan II

\begin{tabular}{|c|l|c|c|c|}
\hline \multirow{2}{*}{ No } & \multicolumn{1}{|c|}{ Aspek } & \multicolumn{2}{c|}{ Hasil Siklus } & \multirow{2}{*}{$\begin{array}{c}\text { Rata-rata } \\
\text { Indikator (KD) }\end{array}$} \\
\cline { 3 - 4 } & & $\mathbf{1}$ & $\mathbf{2}$ & \\
\hline 1 & $\begin{array}{l}\text { Tingkat Kualitas Praktik } \\
\text { Pembelajaran }\end{array}$ & 88,07 & 92,69 & 90,38 \\
\hline 2 & Ketuntasan Hasil Belajar & 78,57 & 96,43 & 87,50 \\
\hline 3 & Rata-rata Nilai & 83,32 & 94,56 & 88,94 \\
\hline
\end{tabular}


Tabel 6. Menunjukkan bahwa dari 4 aspek yang diteliti, ternyata pada masing-masing aspek terjadi perbaikan yang teratur dan berkesinambungan (continous quality improvement). Kedua siklus menggunakan RPP dan Instrumen penilaian yang berbeda dengan model pembelajaran interaksi dengan metode tanya jawab.

Perbaikan/peningkatan yang teratur dan berkesinambungan adalah sebagai berikut:

a. Tingkat kualitas pembelajaran setelah diberikan tindakan naik dari siklus I sebesar $88,07 \%$, siklus II sebesar 92,69\% dan rata-rata sebesar 90,38\% dengan kategori berkualitas

b. Ketuntasan hasil belajar setelah diberikan tindakan naik dari tes awal 50,00\% menjadi siklus I sebesar 78,57\%, siklus II sebesar 96,43\%, dan rata-rata sebesar $87,50 \%$ dengan kategori baik

c. Rata-rata hasil belajar setelah diberikan tindakan naik dari siklus I sebesar 83,32, siklus II sebesar 94,56 dan rata-rata kedua siklus 88,94 dengan karegori sangat baik.

Perbandingan pencapaian hasil kedua siklus untuk dua aspek yang diteliti, terbukti terjadi perbaikan/peningkatan mutu yang berkesinambungan.

\section{Pembahasan}

Rendahnya aktivitas belajar IPA diketahui berdasarkan hasil observasi pembelajaran IPA prasiklus pada pokok bahasan perkembangbiakan makhluk hidup di kelas 6 MI NU Al Huda 01 Padurenan. Hasil tes awal prasiklus yang memperoleh persentase sebesar 50\%, kemudian aktivitas individu siswa pada prasiklus ternyata dapat berpengaruh terhadap hasil belajar IPA pada pokok bahasan perkembangbiakan makhluk hidup di kelas 6 MI NU Al Huda 01 Padurenan yang dibuktikan berdasarkan tingkat ketuntasan hasil belajar prasiklus, bahwa siswa yang tuntas atau telah mencapai KKM (70) hanya 14 siswa dengan persentase sebesar 50\%, sedangkan siswa yang belum tuntas masih setengah dari jumlah siswa.

Berdasarkan data tersebut maka perlu dilakukan tindakan perbaikan proses pembelajaran dengan meningkatkan aktivitas belajar agar hasil belajar IPA siswa 
kelas 6 MI NU Al Huda 01 Padurenan dapat meningkat melalui penerapan model pembelajaran Interaktif menggunakan metode Tanya jawab.

Setelah pembelajaran IPA dengan menerapkan model pembelajaran interaktif menggunakan metode Tanya jawab meliputi langkah pembelajaran kegiatan pengantar, memperbaiki cara penyajian pembelajaran, menambahkan metode pembelajaran (tanya jawab) dan model Pembelajaran Interaktif, memberikan informasi pembelajaran yang jelas dan rinci, memberikan contoh cara memelihara lingkungan agar tetap sehat, memberikan latihan secukupnya, serta menilai belajar dan refleksi dilaksanakan secara keseluruhan pada siklus I dan siklus II. Ternyata siswa lebih berpartisipasi aktif dan interaktif dalam proses pembelajaran. Terbukti dari data hasil observasi aktivitas individu dan kelompok siswa yang telah dipaparkan pada tabel 2 dan tabel 3 diatas.

Meningkatnya aktivitas belajar diikuti dengan peningkatan hasil belajar IPA yang terlihat dari peningkatan nilai rata-rata kelas siklus 1 memperolehan skor ratarata $88,07 \%$ masuk kriteria baik dengan indikator keberhasilan 78,57\%. Namun, pencapaian tersebut belum mencapai indikator keberhasilan yang telah ditentukan peneliti yaitu sebesar 85\% ketuntasan klasikal, oleh karena itu diadakan refleksi sebagai perbaikan pada siklus II. Pada siklus II diperoleh nilai rata-rata kelas meningkat mencapai rata-rata $92.69 \%$ kriteria sangat baik dengan indikator keberhasilan mencapai 96,43\%. Berdasarkan hasil pencapaian ketuntasan pada siklus II, maka hasil pelaksanaan tindakan pada siklus II telah mencapai indikator ketuntasan yang ditetapkan peneliti sebesar $85 \%$ siswa tuntas.

Keberhasilan peningkatan aktivitas dan hasil belajar IPA pada pokok bahasan perkembangbiakan makhluk hidup pada perkembangan dan pertumbuhan manusia dari bayi sampai lanjut usia, terjadi karena penerapan langkah-langkah atau sintaks model pembelajaran interaktif dengan menambahkan metode pembelajaran (tanya jawab). Dalam proses pembelajaran guru bertindak sebagai fasilitator yang membimbing, mengawasi, mengarahkan, menanya dan mengkoordinasi kegiatan serta aktivitas siswa sehingga siswa lebih aktif dan dapat berpikir secara matematik dalam pemecahan masalah. Kegiatan itu membuat siswa benar-benar memahami apa yang telah dipelajarinya dan membuat suasana pembelajaran menjadi interaktif dan 
menyenangkan. Sehingga dapat meningkatkan hasil belajar IPA pada pokok bahasan perkembangbiakan makhluk hidup.

Berdasarkan uraian penelitian yang telah dipaparkan, maka penerapan model pembelajaran Interaktif menggunakan metode Tanya jawab dalam pembelajaran Ilmu Pengetahuan Alam (IPA) di kelas 6 Semester I MI NU Al Huda 01 Padurenan Tahun Pelajaran 2018/2019 ini selaras dengan penelitian sebelumnya oleh penelitian yang dilakukan oleh Dwi Agung Susanto (2012) dengan menerapkan model pembelajaran Interaktif mencapai ketuntasan 81\%, penelitian Nugroho Widiantono (2016) dengan menerapkan model pembelajaran Interaktif mencapai ketuntasan 81,25\%, dan Aminah (2017) dengan menerapkan model pembelajaran Interaktif mencapai ketuntasan 93,33\%. Sedangkan dalam penelitian ini ketuntasan belajar mencapai 96,43\%. Dari hasil penelitian tersebut terbukti bahwa penerapan model pembelajaran Interaktif dengan metode Tanya jawab dapat meningkatkan aktivitas belajar dan hasil belajar.

Persamaan dengan penelitian sebelumnya sama-sama menggunakan model pembelajaran interaktif dan hasilnya terbukti mampu meningkatkan hasil belajar pada siswa. Namun, dalam penelitian ini terdapat perbedaan yaitu dalam meningkatkan hasil belajar lebih memfokuskan pada perbaikan proses belajar dengan metode Tanya jawab. Dalam upaya meningkatkan aktivitas belajar dilakukan dengan menerapkan langkah-langkah mempersiapkan rencana perbaikan pembelajaran sebaik mungkin, menggunakan alat bantu yang tepat dan lengkap untuk menanamkan konsep pembelajaran, memperbaiki cara penyajian pembelajaran, menambahkan metode pembelajaran (tanya jawab) dan model Pembelajaran Interaktif, memberikan informasi pembelajaran yang jelas dan rinci, memberikan contoh cara memelihara lingkungan agar tetap sehat, memberikan latihan secukupnya, dan menindaklanjuti pembelajaran melalui pekerjaan rumah (Primadiati \& Djukri, 2017).

Dalam penelitian ini, model pembelajaran interaktif dengan metode tanya jawab ditambahkan modifikasi kegiatan atau aktivitas seperti yang diuraikan dalam tabel 1. Modifikasi tersebut ditambahkan pada tahap pengantar dengan memberikan keleluasaan kepada siswa tentang bagaimana cara siswa belajar, yaitu belajar secara individu atau kerja kelompok. Dengan memberikan keleluasaan kepada siswa dalam memilih cara belajarnya siswa dapat merasa nyaman dan senang mengikuti 
pembelajaran. Kemudian pada tahap aktivitas penyelesaian masalah dimodifikasi dengan memberi siswa keleluasaan cara tanya jawab. Modifikasi dalam kegiatan atau aktivitas tersebut dapat membantu guru dalam upaya menarik minat siswa mengikuti pembelajaran karena siswa diberikan keleluasaan dalam belajar. Selain itu guru lebih dimudahkan dalam memberikan pembelajaran karena siswa yang aktif menggali informasi dari tanya jawab tersebut, kemudian guru memfasilitasi siswa, memberikan bimbingan dan arahan.

Berdasarkan paparan di atas, maka penelitian ini telah memberikan kontribusi ilmu yaitu model pembelajaran interaktif dengan metode tanya jawab menurut Primadiati \& Djukri yang diberi modifikasi dalam kegiatan atau aktivitas pembelajaran lebih berorientasi pada siswa. Kontribusi ilmu pertama yaitu siswa diberi keleluasaan untuk menentukan cara mereka belajar, secara individu atau kerja kelompok. Kemudian siswa dimungkinkan untuk dapat melakukan berbagai kegiatan atau aktivitas dalam pembelajaran, diantaranya diskusi, tanya jawab dan membuat proyek dengan menyesuaikan materi pembelajaran.

Mengacu pada penjelasan di atas dapat dipaparkan implikasi teoritis bahwa dengan penggunaan model pembelajaran interaktif dengan metode tanya jawab, penelitian ini telah memberikan gambaran bagaimana penerapanya dalam pembelajaran IPA, sehingga dapat meningkatkan aktivitas dan hasil belajar. Selain itu kegiatan pembelajaran sudah disesuaikan dengan EEK (Eksplorasi, Elaborasi, dan Konfirmasi) dan menambahkan modifikasi dalam pembelajarannya, maka telah mengalami perubahan dari teori aslinya. Sedangkan implementasi praktis, ternyata melalui penerapan model pembelajaran interaktif dengan metode tanya jawab dalam pembelajaran IPA, siswa lebih aktif dan berani mengungkapkan rasa ingin tahunya melalui pertanyaan dan berpendapat, sehingga dapat meningkatkan aktivitas dan hasil belajar. Selain itu, guru dapat menciptakan suasana interaktif dalam pembelajaran IPA menggunakan model pembelajaran interaktif dengan metode tanya jawab. Model pembelajaran interaktif dengan metode tanya jawab dapat menjadi alternatif pilihan untuk mengatasi permasalahan siswa yang pasif. Berdasarkan pembahasan tersebut, maka tujuan penelitian telah tercapai bahwa penerapan model pembelajaran interaktif dengan metode tanya jawab dalam pembelajaran IPA pada siswa kelas 6 MI NU Al Huda 01 Padurenan dapat meningkatkan aktivitas dan hasil belajar IPA. 


\section{Simpulan}

Berdasarkan hasil analisis data penlitian tindakan kelas ditarik simpulan bahwa penerapan model pembelajaran interaktif dengan metode tanya jawab dalam pembelajaran perkembangan makhluk hidup dan pelestarian jenis makhluk hidup untuk mencegah dari kepunahan dapat meningkatkan hasil belajar pada mata pelajaran IPA kelas VI MI NU Al Huda 01 Padurenan Gebog Kudus Jawa Tengah semester ganjil tahun pelajaran 2018/2019. Simpulan ini diperkuat dengan hasil sebagai berikut: 1) Ketuntasan hasil belajar pra siklus sebesar 50,00\%, siklus I sebesar 78,57\%, dan siklus II sebesar 96,43\%, dimana terjadi perbaikan yang sangat bermakna; 2) Perbaikan Tingkat kualitas pembelajaran pada siklus I sebesar 88,07\%, dan siklus II sebesar 93,03\%; artinya, perbaikan proses pembelajaran secara bermakna sebagai inti dari penelitian tindakan kelas. 


\section{Daftar Pustaka}

As, A., \& Paudi, I. 2013. Penerapan Metode Eksperimen Untuk Meningkatkan Hasil Belajar IPA Pada Siswa Kelas V SDN I Kombo Kecamatan Dampal Selatan Kabupaten Tolitoli. Jurnal Kreatif Tadulako Online, Vol.5 No.1(10), ISSN 23542614X, 159-172.

Dasna, I. W. 2015. Modul: Desain dan Model Pembelajaran Inovatif dan Interaktif, Universitas Terbuka,. (Online), ((https://repository.ut.ac.id/ 4324/1/MPDR5203M1.pdf)), 1-61.

Dewi, M. P., \& Kristin, F. 2017. Meningkatkan Hasil Belajar Ipa Melalui Metode Inquiry Pada Siswa Kelas V Sd. Mimbar Sekolah Dasar, Vol. 4(1), 67-78. https://doi.org/10.23819/mimbar-sd.v4i1.6346

Haryanti, N. 2013. Upaya Peningkatan Hasil Belajar IPA Melalui Pendekatan Keterampilan Proses pada Siswa Kelas IV SD Inpres Kabuyu Jurnal Kreatif Tadulako Online Vol . 1 No . 4 ISSN 2354-614X. Jurnal Kreatif Tadulako Online, 1(4), 67-77.

Ifan Sofian. 2013. Model Pembelajaran Interaktif Dengan Menggunakan Pendekatan Konstruktivisme Untuk Meningkatkan Prestasi Belajar Fisika Siswa Kelas VIII SMP Negeri 5 Lingsar Tahun Pelajaran 2012/2013. Jurnal Lensa Kependidikan Fisika, Vol.1 No.1, ISSN: 2338-4417, 55-60.

Marliyah. 2014. Upaya Meningkatkan Hasil Belajar IPA Melalui Pnggunaan Alat Peraga Konkrit pada Siswa. Jurnal Pancaran, 3(4), 153-162.

Nisa Wiyati Ilahi, N. I. 2016. Peran Guru Sebagai Manajer dalam Meningkatkan Efektivitas Proses Pembelajaran The Role of Teacher as Manager to Increase Effective Learning Process. Jurnal Pendidikan Manajemen Perkantoran, Vol.1 No.1, 104-114.

Nugroho Widiantono, N. H. 2013. Penerapan Model Pembelajaran Interaktif Untuk Meningkatkan Aktivitas dan Hasil Belajar IPA Siswa Kelas 5 SD. Animal Genetics, 39(5), 561-563.

Primadiati, I. D., \& Djukri, D. 2017. Pengaruh Model Collaborative Learning Terhadap Peningkatan Motivasi dan Hasil Belajar IPA Siswa Kelas IV SD. Jurnal Prima Edukasi, 5(1), 47-57. Retrieved from https://journal.uny.ac.id/index.php/jpe/article/view/7712/pdf

Rusman. 2010. Model-model Pembelajaran: Mengembangkan Profesionalisme Guru. Jakarta: Rajawali Press.

Samatowa U. 2006. Bagaimana Membelajarkan IPA di Sekolah Dasar. Jakarta: Direktorat Pendidikan Nasional.

Silbermen. 2006. Active Learning (101 Cara Belajar Siswa Aktif). Bandung: Nuansa Madia.

Sulistyorini S. 2007. Pembelajaran IPA Sekolah Dasar. Yogyakarta: Tiara Wacana.

Wijaya, C. dan S. 2013. Penelitian Tindakan Kelas. Medan: IKIP. 